\title{
Draft genome sequences of Ceratocystis eucalypticola, Chrysoporthe cuben- sis, C. deuterocubensis, Davidsoniella virescens, Fusarium temperatum, Graphilbum fragrans, Penicillium nordicum, and Thielaviopsis musarum
}

Brenda D. Wingfield ${ }^{1}$, Irene Barnes ${ }^{1}$, Z. Wilhelm de Beer ${ }^{2}$, Lieschen De Vos ${ }^{1}$, Tuan A. Duong ${ }^{1}$, Aquillah M. Kanzi ${ }^{1}$, Kershney Naidoo $^{1}$, Hai D.T. Nguyen ${ }^{3}$, Quentin C. Santana ${ }^{1}$, Mohammad Sayari' ${ }^{1}$, Keith A. Seifert ${ }^{3}$, Emma T. Steenkamp ${ }^{2}$, Conrad Trollip ${ }^{1}$, Nicolaas A. van der Merwe ${ }^{1}$, Magriet A. van der Nest ${ }^{1}$, P. Markus Wilken ${ }^{1}$, and Michael J. Wingfield ${ }^{1}$

\begin{abstract}
1Department of Genetics, Forestry and Agricultural Biotechnology Institute (FABI), University of Pretoria, Private Bag X20, Pretoria, 0028 South Africa; corresponding author e-mail: brenda.wingfield@fabi.up.ac.za

${ }^{2}$ Department of Microbiology and Plant Pathology, Forestry and Agricultural Biotechnology Institute (FABI), University of Pretoria, Private Bag X20, Pretoria, 0028 South Africa

${ }^{3}$ Biodiversity (Mycology), Ottawa Research and Development Centre, Agriculture and Agri-Food Canada, 960 Carling Avenue, Ottawa, Ontario, K1A 0C6, Canada
\end{abstract}

\begin{abstract}
The genomes of Ceratocystis eucalypticola, Chrysoporthe cubensis, Chrysoporthe deuterocubensis, Davidsoniella virescens, Fusarium temperatum, Graphilbum fragrans, Penicillium nordicum and Thielaviopsis musarum are presented in this genome announcement. These seven genomes are from plant pathogens and otherwise economically important fungal species. The genome sizes range from $28 \mathrm{Mb}$ in the case of $T$. musarum to $45 \mathrm{Mb}$ for Fusarium temperatum. These genomes include the first reports of genomes for the genera Davidsoniella, Graphilbum and Thielaviopsis. The availability of these genome data will provide opportunities to resolve longstanding questions regarding the taxonomy of species in these genera. In addition these genome sequences through comparative studies with closely related organisms will increase our understanding of how these pathogens cause disease.
\end{abstract}

\section{Key words: \\ Ceratocystis wilt}

Chrysoporthe canker conifer-infesting beetles

Davidsoniella sapstreak disease mycotoxins in maize

mycotoxin ochratoxin $\mathrm{A}$

stem-end rot of banana

\section{IMA Genome-F 5A}

\section{Draft genome sequence of Ceratocystis eucalypticola}

Many species of Ceratocystidaceae have been studied extensively due to their significance as pathogens of agricultural forestry crops (Roux \& Wingfield 2009), as well as their impact on natural woody ecosystems (Roux et al. 2007, Lee et al. 2015). The family includes eight genera accommodating more than 80 phylogenetically closely related but often morphologically similar species (van Wyk et al. 2013, de Beer et al. 2014, Mayers et al. 2015). These genera, as defined by de Beer et al. (2014), are clearly delimited based on a combination of phylogenetic inference, morphology, and in some cases distinct ecological partitioning. For example, the genus Huntiella accommodates species that are saprobes, whereas most species of Ceratocystis are pathogens of angiosperms.

Species of Ceratocystis include important pathogens of trees propagated as non-natives in plantations in the tropics and Southern Hemisphere (Roux \& Wingfield 2013, Wingfield et al. 2013), including Eucalyptus (Laia et al. 1999, Roux et al. 2000, Roux et al. 2001, Barnes et al. 2003). Isolates of Ceratocystis from Eucalyptus in South Africa, related to those known to kill trees in these plantations, were described as the new species C. eucalypticola (van Wyk et al. 2012). The taxonomy of this species and some of its relatives remains open to debate (Fourie et al. 2015, Oliveira et al. 2015) and there is a clear need to gain a deeper understanding of species boundaries as well as issues relating to its biology and ecology.

The aim of this study was to sequence the genome of C. eucalypticola in order to allow for genomic analysis and comparisons with already available genomes from other Ceratocystidaceae (Wilken et al. 2013, van der Nest et al. 2014a, b). These comparisons, coupled with phylogenomic studies, will be useful in resolving the taxonomic debates ongoing in Ceratocystis. Additionally, these resources will provide a platform to characterise factors associated with pathogenicity and fungal ecological strategy, as well as provide an opportunity to study the evolution of these traits within a family of closely related fungi.

๑ 2015 International Mycological Association

You are free to share - to copy, distribute and transmit the work, under the following conditions:

Attribution: $\quad$ You must attribute the work in the manner specified by the author or licensor (but not in any way that suggests that they endorse you or your use of the work)

Non-commercial: $\quad$ You may not use this work for commercial purposes.

No derivative works: You may not alter, transform, or build upon this work.

For any reuse or distribution, you must make clear to others the license terms of this work, which can be found at http://creativecommons.org/licenses/by-nc-nd/3.0/legalcode. Any of the above conditions can be waived if you get permission from the copyright holder. Nothing in this license impairs or restricts the author's moral rights. 


\section{SEQUENCED STRAIN}

South Africa: Mpumalanga: Sabie, isol. ex artificial wound of Eucalyptus, July 2002, M. van Wyk \& J. Roux (CMW 9998, CBS 124017, PREM 60169 - dried culture).

\section{NUCLEOTIDE SEQUENCE ACCESSION NUMBER}

The draft genome sequence of Ceratocystis eucalypticola (CMW9998) has been deposited at DDBJ/EMBL/GenBank with the accession number LJOA00000000. Here we describe version LJOA01000000.

\section{METHODS}

Genomic DNA of Ceratocystsis eucalypticola isolate CMW 9998 was sequenced using the Illumina HiSeq 2000 platform at the UC Davis Genome Centre, University of California, Davis (CA). Two libraries with medium insert sizes of $350 \mathrm{bp}$ and $530 \mathrm{bp}$ were used to generate pair-end sequences with read lengths of approximately 100 bases. CLC Genomics Workbench v. 7.5.1 (CLCBio, Aarhus, Denmark) was used to analyse the NGS-data, as well as to perform a de novo assembly. Reads of low quality ( $P$ error limit of 0.05 ) and/or terminal nucleotides were trimmed, with the remaining reads being retained for assembly. De novo genome assembly was performed with a word size of 64 , and a bubble size of $100 \mathrm{bp}$. The raw reads were mapped back to the contigs in order to perform scaffolding, with an estimated paired distance ranging from 147 to $654 \mathrm{bp}$. The completeness of the assembled genome was assessed using the Benchmarking Universal Single-Copy Orthologs tool, BUSCO (Software v. 1.1b1 of May 2015) (Simão et al. 2015). BUSCO was performed on all contigs $>1 \mathrm{~kb}$, making use of the fungal lineage dataset. Lastly, the assembly was submitted to AUGUSTUS (Stanke et al. 2004) in order to predict putative open reading frames (ORFs) using the gene models of Fusarium graminearum.

\section{RESULTS AND DISCUSSION}

The draft genome of Ceratocystis eucalypticola had an estimated size of 31260284 bases, with an N50 of 116489 and an average coverage of $80 x$. The de novo assembly generated a total of 2129 contigs, of which 961 were longer than $1 \mathrm{~kb}$. The average scaffold length was 14676 bases, with the largest scaffold being 726305 bases in size. The GC content of the assembly was $47.9 \%$. BUSCO analysis defined the genome as $97 \%$ complete with 1408 single-copy orthologs present, while 92 BUSCO orthologs were found to be duplicated. Only 30 BUSCO orthologs were missing or fragmented out of the possible 1438 groups searched from the fungal lineage dataset. Gene prediction resulted in a total of 7353 putative ORFs, at a gene density of approximately $235 \mathrm{ORFs} / \mathrm{Mb}$.

The assembled genome of $C$. eucalypticola, with a size of approximately $31.2 \mathrm{Mb}$ and $7353 \mathrm{ORFs}$, closely resembled those of other sequenced Ceratocystis spp. (Wilken et al. 2013, van der Nest et al. 2014a, b). The fungus had a genome size most similar to that of $C$. fimbriata $(29.4 \mathrm{Mb}$, 7266 ORFs) and C. manginecans (31.7 Mb, 7494 ORFs), while the $C$. albifundus genome is slightly smaller $(27.2 \mathrm{Mb})$ with only 6967 genes predicted. The genome size statistics for Ceratocystis are similar to those found in the genus Huntiella, with $H$. omanensis and $H$. moniliformis being $31.5 \mathrm{Mb}$ and $25 \mathrm{Mb}$, respectively (van der Nest et al. 2014a, b). Gene predictions for Huntiella showed a slightly higher gene density when compared with those of Ceratocystis (243 ORFs/Mb on average), with $\mathrm{H}$. omanensis having a density of $266 \mathrm{ORFs} / \mathrm{Mb}$ and $H$. moniliformis having $280 \mathrm{ORFs} / \mathrm{Mb}$, respectively.

The availability of these resources will provide opportunities to answer questions regarding the similarities and differences seen in this genus. The genome data for Ceratocystis s. str. is particularly useful for exploring the species boundaries through phylogenomic analysis. This, in combination with genomic comparisons to other species within Ceratocystidaceae, will lead to a better understanding of the evolution of pathogenicity and other life history traits.

Authors: C. Trollip*, T.A. Duong, M.A. van der Nest, I. Barnes, M.J. Wingfield, and B.D. Wingfield ${ }^{\star}$ Contact: Conrad.Trollip@fabi.up.ac.za

\section{IMA Genome-F 5B}

\section{Draft genome sequences of Chrysoporthe cubensis and $C$. deuterocubensis, causal agents of Eucalyptus canker}

Fungi in the genus Chrysoporthe are economically important pathogens of plantation grown Eucalyptus spp. and other members of Myrtales (Gryzenhout et al. 2004). These fungi cause serious stem canker disease, referred to as Chrysoporthe canker (Gryzenhout et al. 2004), and are predominantly found in tropical and subtropical parts of the world where conditions favour their growth (Alfenas et al. 1982). Although Chrysoporthe canker has been successfully managed through propagation of disease resistant clones, it is still considered a threat since it can lead to substantial economic losses where resistance breeding is not in place (Wingfield 2003).

There are eight described species of Chrysoporthe, including C. cubensis (Hodges et al. 1976, 1979, Rodas et al. 2005), C. doradensis (Gryzenhout et al. 2005), C. inopina (Gryzenhout et al. 2006), and C. hodgesiana (Gryzenhout et al. 2004) which occur in South and Central America. Chrysoporthe deuterocubensis is primarily found in Southeast Asia, although introductions to Australia, China, Hawaii, and parts of East Africa have been suggested (Myburg et al. 2002, Nakabonge et al. 2006, van der Merwe et al. 2010). Chrysoporthe zambiensis and C. syzygiicola are found in Zambia (Chungu et al. 2010), while C. austroafricana is found only in southern Africa (Wingfield et al. 1989, Gryzenhout et al. 2004). 
Table 1. Comparison of whole genome sequencing assembly features for Chrysoporthe cubensis, C. Deuterocubensis, and C. austroafricana (Wingfield et al. 2015).

\begin{tabular}{llll}
\hline Measure & $\begin{array}{l}\text { C. austroafricana } \\
\text { (CMW 2113) }\end{array}$ & $\begin{array}{l}\text { C. deuterocubensis } \\
\text { (CMW 8650) }\end{array}$ & $\begin{array}{l}\text { C. cubensis } \\
\text { (CMW 10028) }\end{array}$ \\
\hline \hline Genome size & 44669169 & 43969123 & 42624564 \\
GC & $53.9 \%$ & $55 \%$ & $54.9 \%$ \\
Contigs & 6416 & 6500 & 3326 \\
Scaffolds (SSPACE) & 3232 & 2574 & 954 \\
Gene models (Augustus) & 13484 & 13772 & 13121 \\
Completeness (BUSCO) & $94 \%$ & $95 \%$ & $94 \%$ \\
\hline
\end{tabular}

Chrysoporthe cubensis, C. deuterocubensis, and C. austroafricana have been isolated from native trees, suggesting that these fungi might be native to the regions where the trees are found (Myburg et al. 2003, Rodas et al. 2005, Heath et al. 2006). Interestingly, despite the distinct geographical distribution, these species seem to be closely related (Chungu et al. 2010, van der Merwe et al. 2010). Unfortunately, there is limited available information regarding the evolution of Chrysoporthe species.

The genome of $C$. austroafricana was recently sequenced and released in the public domain (Wingfield et al. 2015). This is the only whole genome sequence resource available for the genus Chrysoporthe. Additional genomic resources could enhance further understanding of the biology of this assemblage of fungi, through genome-wide comparisons. The aim of this study was thus to sequence the genomes of $C$. cubensis (isolate CMW 10028) and C. deuterocubensis (isolate CMW 8650).

\section{SEQUENCED STRAINS}

Chrysoporthe cubensis: Colombia: Timba, 2002, C.A. Rodas (CMW 10028, PREM 58311 - dried culture).

Chrysoporthe deuterocubensis: Indonesia: Sulawesi, 2001, M.J. Wingfield (CMW 8650, CBS 115719, PREM 58018 dried culture).

\section{NUCLEOTIDE SEQUENCE ACCESSION NUMBER}

The Chrysoporthe cubensis isolate number CMW 10028 and C. deuterocubensis isolate CMW 8650 Whole Genome Shotgun projects were deposited in GenBank with accession numbers LJCY00000000 and LJDD00000000, respectively. The version described here is LJCY00000000 and LJDD00000000 for $C$. cubensis and $C$. deuterocubensis, respectively.

\section{MATERIALS AND METHODS}

Genomic DNA was extracted using a modified protocol (Steenkamp et al. 1999) from isolate CMW 10028 (Chrysoporthe cubensis) and CMW 8650 (C. deuterocubensis) mycelium obtained from 7-d-old fungal cultures. The Illumina MiSeq paired-end sequencing protocol at the Agricultural Research Council (ARC, South Africa) was used to obtain whole genome sequence data. To assemble the pairedend MiSeq sequences, CLC Genomics Workbench v. 7.5.1 (CLCBio, Aarhus, Denmark) was used. The assemblies were subsequently scaffolded using SSPACE v. 2.0 (Boetzer et al. 2011), which included unused MiSeq reads from the CLC Genomics Workbench assembly. The AUGUSTUS (Stanke \& Morgenstern 2005) protein coding gene prediction software was used for de novo annotation of protein coding gene models using Neurospora crassa and Fusarium graminearum as references. Genome completeness was assed using BUSCO (Benchmarking Universal Single-Copy Orthologs) which utilizes single-copy orthologs to predict genome completeness (Simão et al. 2015).

\section{RESULTS AND DISCUSSION}

The approximate size of the Chrysoporthe cubensis genome was 42624564 base pairs (bp) including gaps, while the C. deuterocubensis assembly was 43969123 bp in size. These figures were calculated from 989 and 2599 scaffolds for $C$. cubensis and $C$. deuterocubensis, respectively. From the AUGUSTUS analysis, 12435 gene models were predicted from the $C$. cubensis genome, while 13098 gene models where predicted in the $C$. deuterocubensis genome. Despite the differences observed in the assembly statistics, the CEGMA analysis for genome completeness in both $C$. cubensis and C. deuterocubensis was predicted at $95.16 \%$.

Compared to the closely related $C$. austroafricana genome, that of $C$. cubensis was slightly smaller, while the C. deuterocubensis genome was slightly larger. Similarly, C. cubensis had fewer predicted gene models than either C. austroafricana or C. deuterocubensis (Table 1). In terms of gene content, the Chrysoporthe spp. genomes were slightly larger than that of the distantly related Cryphonectria parasitica (43.9 Mb, 11184 gene models) (http://genome. jgi.doe.gov/Crypa2/Crypa2.info.html) although the genome sizes were relatively close, and the model filamentous fungi, Neurospora crassa (39.9 Mb, 10082 gene models) (Galagan et al. 2003) and Magnoporthe grisea (40.3 Mb, 11109 gene models) (Dean et al. 2005).

The significance of differences observed in genome size and the number of predicted genes among the Chrysoporthe species is not known. However, it might be speculated that their geographical distribution could have played a role in the evolution of these genomes. The availability of these genomes will make it possible to answer such phylogeographic 


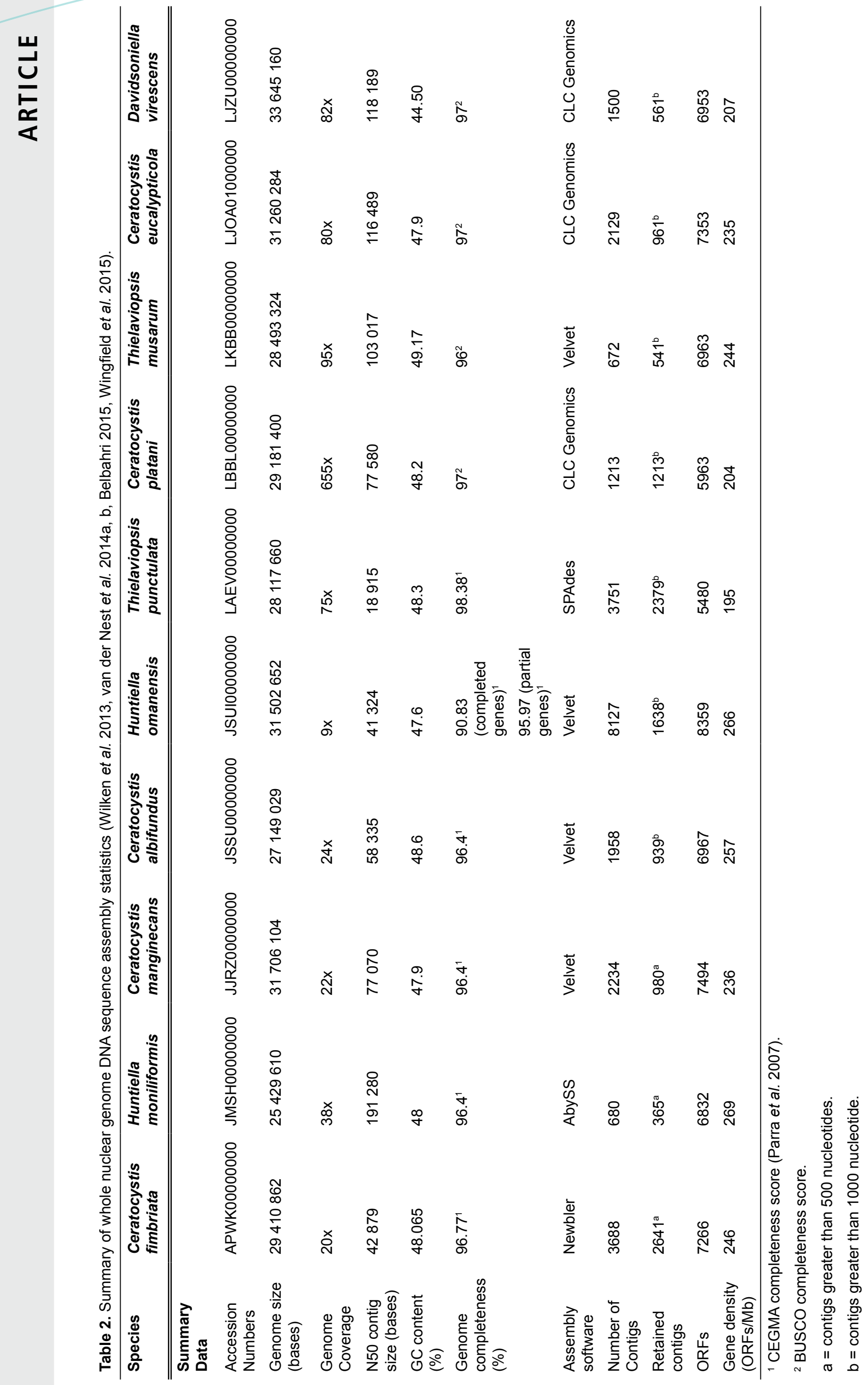


questions and will aid in addressing questions relating to the biology of Chrysoporthe species.

Authors: A.M. Kanzi, B.D. Wingfield, M.J. Wingfield, E.T. Steenkamp, and N. A. van der Merwe* ${ }^{*}$ Contact: albe.vdmerwe@up.ac.za

\section{NUCLEOTIDE SEQUENCE ACCESSION NUMBER}

The Whole Genome Shotgun project of the Davidsoniella virescens genome has been deposited at DDBL/EMBL/ GenBank under the accession no. LJZU00000000. The version described in this paper is version LJZU01000000.

\section{METHODS}

\section{Draft nuclear genome sequence for Davidsoniella virescens, the causal agent of sapstreak disease in hardwood trees}

The newly recognized genus Davidsoniella (de Beer et al. 2014) includes species previously accommodated in the Ceratocystis coerulescens s. lat. clade. Davidsoniella virescens is a tree pathogen that infects hardwood trees such as Acer saccharum (sugar maple) in eastern North America (Davidson 1944). This fungus is highly pathogenic to sugar maple in plantations, where it feeds on the sugars and other carbohydrates in the wood of the trees (Bal et al. 2013). The disease caused by D. virescens is commonly referred to as sapstreak and the fungus affects the internal wood chemistry where it has been implicated in the production of volatiles that can enhance the growth of other fungi (Wargo \& Harrington 1991).

The aim of this study was to assemble a draft nuclear genome sequence of $D$. virescens, which would ultimately allow for comparative studies with other sequenced genomes in Ceratocystidaceae. The genomes of seven other species of Ceratocystidaceae are publically available to aid with such a comparative analyses. These include Ceratocystis fimbriata, a pathogen affecting sweet potatoes (Wilken et al. 2013); the canker and wilt disease causing $C$. albifundus, occurring on Acacia mearnsii trees (van der Nest et al. 2014a); the mango wilt pathogen, C. manginecans (van der Nest et al. 2014b); species in the related genus Huntiella, $H$. moniliformis and $H$. omanensis, saprobic fungi usually found on freshly cut or wounded logs (van der Nest et al. 2014a), the causal agent of black scorch disease in date palms, Thielaviopsis punctulata (Wingfield et al. 2015) and the plane tree pathogen C. platani (Belbahri 2015). Two additional Ceratocystidaceae genomes, those for C. eucalypticola and Thielaviopsis musarum, are included in this issue and collectively, these will add value to the comparative analysis of the genomes across this family. Understanding the general biology of $D$. virescens will further assist in developing a deeper understanding of sap streak and potentially contribute to disease management strategies.

\section{SEQUENCED STRAIN}

USA: New Hampshire: isol. ex Acer saccharum, Aug. 1987, D. Houston (CMW 17339 = CBS 130772; PREM 61293 dried culture).
Davidsoniella virescens isolate CMW 17339 was used in this study. Cultures were grown at $25^{\circ} \mathrm{C}$ on $2 \%$ malt extract agar (MEA: $20 \%$ w/v, Biolab, Midrand, South Africa) supplemented with $100 \mu \mathrm{g} / \mathrm{L}$ thiamine. Total genomic DNA was isolated from 2-wk-old cultures using a phenol-chloroform method previously described (Roux et al. 2004). Sequencing was carried out on the Genomics Analyzer Ilx platform (Illumina) at the Genome Centre (University of California at Davis, CA). Paired-end libraries with insert fragments of 350 and 600 bases were used to generate the read lengths of 100 bases. CLCBio Genomics workbench software v. 7.5.1 (CLCBio, Aarhus, Denmark) was used for quality assessment and de novo assembly. Poor-quality reads (limit of 0.05 ) and/or terminal nucleotides were discarded. The remaining reads were assembled de novo using a word size of 64 with a bubble size of 100 base pairs. Scaffolding with an estimated pair distance of 99 to 562 base pairs was performed by mapping raw reads back to the contigs. Only contigs greater than 1000 bases were retained. Predictions of open reading frames (ORFs) based on the gene model for Fusarium graminearum (http://bioinf.uni-greifswald.de/augustus) were made using AUGUSTUS (Stanke et al. 2006). The quantitative assessment of the genome assembly completeness was assessed against the Benchmarking Universal Single-Copy Orthologs software program, BUSCO (Simão et al. 2015) using contigs greater than 1000 bases in length.

\section{RESULTS AND DISCUSSION}

Davidsoniella virescens had an estimated nuclear genome size of 33645160 bases. The N50 value was determined to be 118189 bases generating a mean GC content of $44.50 \%$. A total of 563 contigs were produced from the CLCBio assembly, of which 561 were retained after excluding the mitochondrial scaffolds. The AUGUSTUS gene prediction pipeline estimated 6953 ORFs. This draft genome assembly had a BUSCO completeness score of $97 \%$ indicating that the core eukaryotic genes were present. From this analysis, 1404 single-copy genes were observed, of which 73 were duplicated genes. Of the 1438 genes searched, only $2.2 \%$ were classified as fragmented or missing. A gene density of 207 ORFs per Mb was observed for the 6953 genes predicted.

Davidsoniella virescens has the largest estimated genome size (33 Mb) of all Ceratocystidaceae genomes sequenced thus far (Table 2). The dissimilarity in the coverage, N50 values and number of contigs can be attributed to the different sequencing and assembly 
platforms used to generate the data (Table 2). The retention of the final number of contigs processed in gene prediction tools also differed because some researchers have chosen to retain smaller contigs (greater than 500 nucleotides). Davidsoniella virescens had a similar GC content and genome completeness to the genomes sequenced of the other species in Ceratocystidaceae (Table 2). Adding to the growing number of sequenced and assembled genomes, the $D$. virescens genome provides a powerful resource to aid in its phylogenetic classification in Ceratocystidaceae. Similar or shared biological features can now be identified due to the availability of these genomes.

Authors: K. Naidoo*, C. Trollip, P.M. Wilken,
M.J. Wingfield, and B.D. Wingfield
${ }^{*}$ Contact: Kershney.Naidoo@fabi.up.ac.za

IMA Genome-F 5D

\section{Nuclear genome assembly for the maize pathogen Fusarium temperatum}

Fusarium temperatum (formerly $F$. subglutinans group 1, de Vos et al. 2014) is an important mycotoxin-producing pathogen of maize (Scauflaire et al. 2011). This fungus is a member of the Fusarium fujikuroi complex which includes numerous pathogens responsible for destructive diseases of many plants (Kvas et al. 2009). Due to the economic importance of the complex, the whole genome sequences for several of its members have been determined and are publicly available. These include F. verticillioides (Fusarium Comparative Sequencing Project, Broad Institute of Harvard and MIT; http://www.broad.mit.edu), F. circinatum (Wingfield et al. 2012), F. fujikuroi and F. mangiferae (Wiemann et al. 2013), as well as F. nygamai (Wingfield et al. 2015).

To complement these genomic resources, genetic linkage maps for some of these fungi are also available (Jurgensen et al. 2002, de Vos et al. 2007). For example, a genetic linkage map available for a hybrid cross between F. circinatum and F. temperatum (de Vos et al. 2007) has been used as a framework in the analyses of certain loci and traits in these fungi (de Vos et al. 2011, 2013). Most recently, an analysis of the genomic architecture of species in this complex, allowed the anchoring of this genetic linkage map to the genomic sequence data for $F$. verticillioides and F. fujikuroi (de Vos et al. 2014). The aim of this study was therefore to determine the whole genome sequence for the other parent ( $F$. temperatum) in this hybrid cross. The availability of genome data for this fungus would allow comparisons to the other sequenced members of the F. fujikuroi complex as well as contribute to improving our knowledge of the genetic processes and properties underlying the biology of these important fungi.

\section{SEQUENCED STRAIN}

Mexico: Texcoco: isol. Zea mays ssp. mexicana seeds (teosinte), Nov. 1996, A.E. Desjardins, R.D. Plattner \& T.R. Gordon (CMW 40964, CBS 138287; PREM 61039 - dried culture).

\section{NUCLEOTIDE SEQUENCE ACCESSION NUMBER}

The Fusarium temperatum genomic sequence data has been deposited at DDBJ/EMBL/GenBank under the accession LJR00000000. The version described in this paper is version LJR01000000.

\section{METHODS}

DNA was extracted from Fusarium temperatum grown on $1 / 2$ PDA (Iturritxa et al. 2011). One mate-pair (2 840 bp average insert size) and two paired-end (average insert sizes of 213 and $476 \mathrm{bp}$ ) libraries were prepared and subjected to 100 bp Illumina HiSeq 2000 sequencing at Fasteris (Geneva). After removing poor quality reads using CLC Genomics Workbench v. 6.5 (CLCbio, Aarhus, Denmark), sequences were assembled using ABySS v. 1.3.7 (Simpson et al. 2009). Closing of gapped regions within the scaffolds was done using GapFiller v. 1.11 (Boetzer \& Pirovano 2012). The completeness of the genome assembly was evaluated using CEGMA (Parra et al. 2008) and putative open reading frames (ORFs) were predicted using AUGUSTUS (Hoff \& Stanke 2013) together with the gene models for $F$. graminearum and cDNA data from the closely related $F$. circinatum (Wingfield et al. 2012). By making use of MUMmer v. 3.22 (Kurtz et al. 2004), the F. temperatum scaffold sequences were compared to the chromosomes of two other sequenced members in the F. fujikuroi complex, F. fujikuroi (Wiemann et al. 2013) and F. verticillioides (Fusarium Comparative Sequencing Project) (De Vos et al. 2014).

\section{RESULTS AND DISCUSSION}

Assembly of 188294812 good quality reads yielded a draft genome for Fusarium temperatum that consisted of 45 458781 bp with $414 x$ coverage. This assembly consists of 43 scaffolds with an N50 of 4506647 bp and an average scaffold size of $1057181 \mathrm{bp}$. Based on the CEGMA analysis, this draft genome is $97.38 \%$ complete (Parra et al. 2008). The GC content is $47 \%$. The assembly contains 14284 putative ORFs with an average length of $1576 \mathrm{bp}$ and an average density of $314 \mathrm{ORFs} / \mathrm{Mb}$. These genome statistics for $F$. temperatum are comparable to those of the other sequenced Fusarium members (Fusarium Comparative Sequencing Project, Wingfield et al. 2012, 2015, Wiemann et al. 2013), which highlights the genomic similarities amongst the members in the F. fujikuroi complex.

Sequence comparisons of the sixteen largest scaffolds (which accounts for $99.56 \%$ of the total genome size) to 


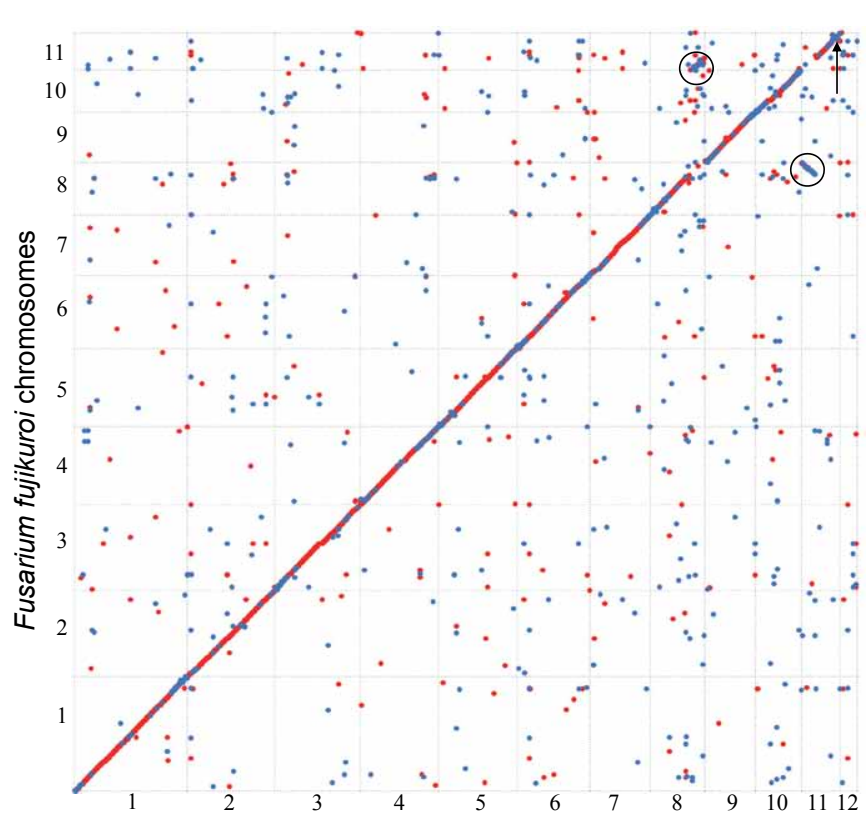

A

Fusarium temperatum chromosomes

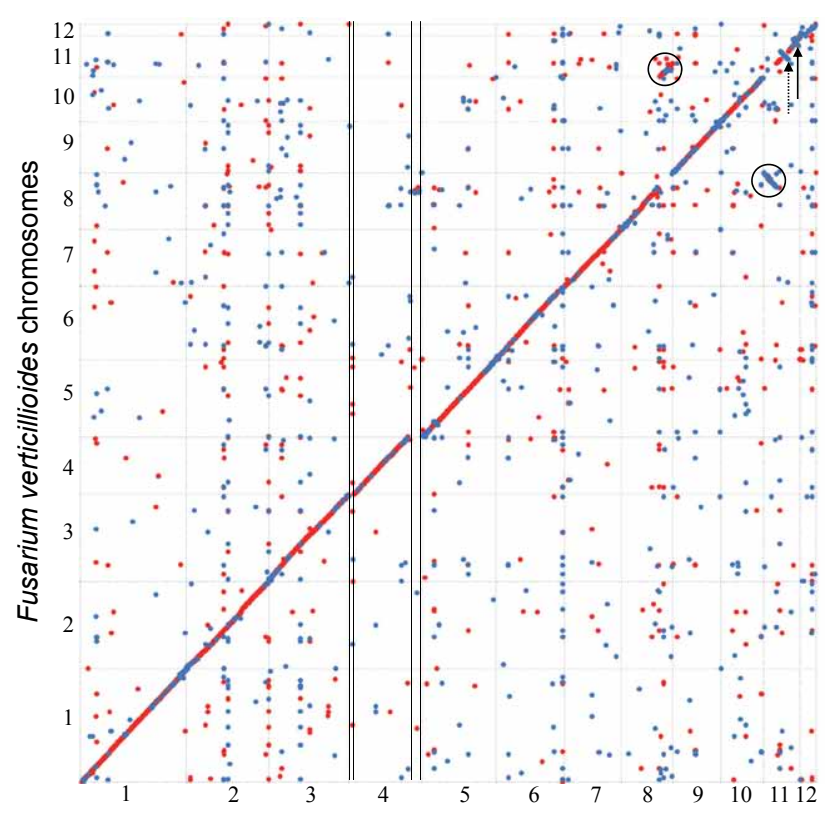

B

Fusarium temperatum chromosomes

Fig. 1. Whole genome comparisons of (A) Fusarium verticillioides to $F$. temperatum, and (B) F. fujikuroi to $F$. temperatum. Dotplot alignments of $F$. verticillioides scaffolds (placed into chromosomes; de Vos et al. 2014) and F. fujikuroi chromosomes (Wiemann et al. 2013) against the 16 largest F. temperatum scaffolds. Forward matches are indicated by red dots, reverse matches with blue dots. The black circles show the reciprocal translocation between chromosome 8 and 11 - the single scaffold representing chromosome 11 has a portion that aligns to chromosome 8 and a portion that align to chromosome 11 of $F$. verticillioides and $F$. fujikuroi. Solid arrows are indicative of inversions in $F$. temperatum, while the dotted arrow indicates an inversion in F. fujikuroi, when compared to the two other Fusarium spp.

the information for the $F$. verticillioides and F. fujikuroi genomes suggests that these scaffolds likely make up the 12 chromosomes predicted for species in the F. fujikuroi complex (Xu et al. 1995). This was further illustrated by the alignments of the F. temperatum scaffolds to the chromosome sequences for $F$. verticillioides and F. fujikuroi (Fig. 1). These alignments also confirmed the reciprocal translocation in F. temperatum and $F$. circinatum observed by de Vos et al. (2014) between chromosomes 8 and 11 (Fig. 1). The subtelomeric regions missing from chromosome 4 in $F$. fujikuroi (Wiemann et al. 2013) are present in F. temperatum (Fig. 1B), confirming that the shortened chromosome 4 is $F$. fujikuroi-specific.

Like F. verticillioides, F. temperatum also harboured the large inversion previously reported in chromosome 11 between $F$. verticillioides and $F$. fujikuroi (Wiemann et al. 2013, de Vos et al. 2014) (Fig. 1B), although F. temperatum appears to have an additional inversion in this chromosome when compared to F. verticillioides and F. fujikuroi (Fig. 1). Sequence comparisons also revealed that chromosome 12 is present in this F. temperatum assembly, albeit 1.42 times larger than its counterpart in F. fujikuroi (Wiemann et al. 2013). Within the F. fujikuroi complex, chromosome 12 has also been shown to be dispensable as well as strain-specific (Xu et al. 1995, Jurgenson et al. 2002, Ma et al. 2010, Wiemann et al. 2013, van der Nest et al. 2014a). Collectively, chromosome 11 and 12 therefore seems to be the most variable of the chromosomes in this complex. The addition of the whole genome sequence of $F$. temperatum, to the other sequenced members of the F. fujikuroi complex, would assist phylogenomic studies into the evolution and biology of these important fungi.

\section{Authors: L. De Vos*, Q.C. Santana, B.D. Wingfield, M.A. van der Nest, M.J. Wingfield, and E.T. Steenkamp *Contact: Lieschen.devos@up.ac.za}

\section{IMA Genome-F 5E}

\section{Draft genome sequence of Graphilbum fragrans}

Graphilbum is one of six currently recognized genera in Ophiostomatales (Ascomycota, Sordariomycetes) (de Beer \& Wingfield 2013). The genus includes nine named species and some undescribed taxa (de Beer \& Wingfield 2013). As with most other species of Ophiostomatales, species of Graphilbum are commonly found associated with coniferous hosts. Graphilbum fragrans was first described in 1954 from Sweden (MathiesenKäärik 1954), where it was initially treated in Graphium (as $G$. fragrans). This species was later reported from conifers or conifer-infesting beetles from various other countries including Australia, Canada, China, New Zealand, Korea, Poland, South Africa, Spain, and the USA (Harrington et al. 2001, Jacobs et al. 2003, Zhou et al. 2006, Kim et al. 2007, Romon et al. 2007, Paciura et al. 2010, Jankowiak \& Bilański 2013). 
The availability of whole genome sequences and recent advancements in genome analyses have contributed to a better understanding of the biology, pathogenicity and evolutionary processes in fungi. A number of genomes of species in Ophiostomatales have been sequenced and analysed, however, these include only species in Leptographium, Ophiostoma, and Sporothrix (DiGuistini et al. 2011, Haridas et al. 2013, Khoshraftar et al. 2013, Teixeira et al. 2014, van der Nest et al. 2014, Wingfield et al. 2015). The aim of this study was to generate the genome sequence for $G$. fragrans, the first genome available for the genus Graphilbum and thus to provide a basis for comparison between the genera of Ophiostomatales.

\section{SEQUENCED STRAIN}

South Africa: Mpumalanga: from Hylastes angustatus infesting Pinus patula, 1999, X.D. Zhou (culture CMW 19357 = CBS 138720; PREM 61294 - dried culture).

\section{NUCLEOTIDE SEQUENCE ACCESSION NUMBER}

The genomic sequence of Graphilbum fragrans (CMW 19357, CBS 138720) has been deposited at DDBJ/EMBL/ GenBank under the accession LLKO00000000. The version described in this paper is version LLKO01000000.

\section{METHODS}

Methods for DNA extraction, genome sequencing, assembly and annotation were similar to those used for Leptographium lundbergii (Wingfield et al. 2015). Total genomic DNA was extracted following the protocol of Duong et al. (2013). Two pair-end libraries (350 bp and $530 \mathrm{bp}$ average insert size) were prepared and sequenced using the Illumina HiSeq 2000 platform. Obtained reads were first subjected to quality filtering and trimming, followed by de novo assembly using CLC Genomics Workbench v. 8.0.1 (CLCBio, Aarhus, Denmark). Genome completeness was estimated using BUSCO (Simão et al. 2015). Total number of gene models was predicted using the MAKER genome annotation pipeline (Cantarel et al. 2008).

\section{RESULTS AND DISCUSSION}

Over 26.2 million reads were obtained after filtering and trimming. De novo assembly using CLC Genomic Workbench resulted in 80 scaffolds that were over $500 \mathrm{bp}$ in size. The assembly had a N50 value of $973.6 \mathrm{~kb}$ and the longest scaffold was $2.66 \mathrm{Mb}$. The genome of Graphilbum fragrans was estimated to be $34.26 \mathrm{Mb}$, with the mean GC content of $55.7 \%$. We assessed the completeness of the obtained genome by running BUSCO on the resulting assembly using the fungal reference dataset and obtained BUSCO values of C: $97 \%$ [D: $5.8 \%$ ], F: $1.8 \%$, M: $0.6 \%$, n: 1348
(C: complete, [D: duplicated], F: fragmented, M: missed, $\mathrm{n}$ : genes), indicating that the obtained genome sequence should cover most of the organism's gene space. Genome annotation using MAKER resulted in 10633 gene models filtered based on MAKER max build (8 942 gene models if MAKER standard build was applied) (Campbell et al. 2014). Of 10633 gene models predicted using MAKER max build, 8102 were multi-exonic genes, mean intron length was 121.1 bp and mean exon length was $552.8 \mathrm{bp}$. The genome of $G$. fragrans, which is the first genome reported for Graphilbum, represents a useful resource for various comparative genomic and systematic studies in Ophiostomatales.

Authors: T.A. Duong*, M.J. Wingfield, Z.W. de Beer, and B.D. Wingfield

*Contact: Tuan.Duong@fabi.up.ac.za

\section{IMA Genome-F 5F}

\section{Draft genome sequence of Penicillium nordicum DAOMC 185683}

Penicillium nordicum is classified in the subgenus Penicillium section Fasciculata (Houbraken \& Samson 2011) and is commonly isolated from cheese, nuts and other fat and protein rich substrates like salami and ham (Frisvad \& Samson 2004). The importance of this fungus relates to its production of the regulated mycotoxin ochratoxin A (OTA), which is hepatoxic, nephrotoxic, teratogenic and immunotoxic in animals (Pitt et al. 2012), known to promote oxidative DNA damage by the production of reactive oxygen species and to generate DNA adducts (Hadjeba-Medjdoub et al. 2012), and is classified as a possible human renal carcinogen (group 2B) by the International Agency for Research on Cancer (IARC, Pitt et al. 2012).

OTA is also produced by $P$. verrucosum, the sister species to $P$. nordicum (Samson et al. 2004), and by several species of Aspergillus (Visagie et al. 2014a). Despite the importance of OTA in grain, coffee and grape products, its biosynthetic pathway has yet to be fully elucidated. However, there is evidence that a gene cluster including an alkaline serine protease, a polyketide synthase and a non-ribosomal peptide synthase may play a role in OTA production in $P$. nordicum (Karolewiez \& Geisen 2005, Geisen et al. 2006). In this study, we sequenced and annotated a genome draft of $P$. nordicum DAOMC 185683, as part of our investigation of genes regulating OTA production in Penicillium species.

\section{SEQUENCED STRAIN}

Canada: Alberta: Brooks, isolated from Lycopersicon esculentum (tomato), collected and isolated 24 Jan. 1983, R.J. Howard GT-78. (DAOMC 185683). Originally identified as Penicillium aurantiogriseum by John D. Bissett; reidentified as $P$. nordicum by Keith A. Seifert in 2012. 


\section{NUCLEOTIDE SEQUENCE AND RAW READS ACCESSION NUMBERS}

This Whole Genome Shotgun project was deposited at DDBJ/ EMBL/GenBank under accession LHQQ00000000. The version described in this paper is version LHQQ01000000. Raw reads were deposited in NCBI SRA (http://www.ncbi. nlm.nih.gov/sra) accession number SRR2146067.

\section{DNA EXTRACTION, WHOLE GENOME SEQUENCING AND ASSEMBLY}

Penicillium nordicum DAOMC 185683 was grown on Blakeslee's malt extract agar for $7 \mathrm{~d}$ at $25^{\circ} \mathrm{C}$ (Visagie et al. 2014b). To make a spore suspension, the colonies were flooded with $5 \mathrm{~mL}$ of sterile distilled water. One $\mathrm{mL}$ of this spore suspension was inoculated in $100 \mathrm{~mL}$ of Blakeslee's malt extract broth and was left shaking at $300 \mathrm{rpm}$ at $25{ }^{\circ} \mathrm{C}$ for $6 \mathrm{~d}$. To obtain fungal tissue for DNA extraction, cells were removed from the liquid culture by filtration. DNA was extracted with the OmniPrep kit for fungi (G-Biosciences) following the manufacturer's protocol. Whole-genome sequencing (pairedend with 101 bp) was performed on an Illumina HiSeq 2500 with TrueSeq V3 chemistry at the National Research Council Canada in Saskatoon (Saskatchewan, Canada).

The quality of genomic reads was determined with FastQC v. 0.10 .1 (http://www.bioinformatics.babraham.ac.uk/projects/ fastqc/). Using fastx_trimmer (part of the FASTX-Toolkit v.0.0.13 (http://hannonlab.cshl.edu/fastx_toolkit/)), 10 bases from the 5' end were trimmed to yield higher quality reads of $91 \mathrm{bp}$. Adaptor sequences were removed with Trimmomatic v. 0.33 (Bolger et al. 2014). Prior to genome assembly, the optimal k parameter was calculated with KmerGenie v. 1.6950 (Chikhi \& Medvedev 2014). Error correction was performed on the trimmed reads with BayesHammer (Nikolenko et al. 2013).

De novo genome assembly was performed with SPAdes v. 3.5.0 (Bankevich et al. 2012) with the option to correct mismatches and short indels enabled. Scaffolds shorter than 1000 bp were discarded. Species identification was confirmed by comparing the internal transcribed spacer (KJ834513) and beta-tubulin (KJ834476) barcode sequences of $P$. nordicum (Visagie et al. 2014b) against the assembled genomic scaffolds using BLASTn. Assembly statistics were generated with QUAST v. 2.3 (Gurevich et al. 2013).

The assembly was assessed by alignment of the corrected reads onto the scaffolds using Bowtie2 v. 2.0.0 (Langmead \& Salzberg 2012). Alignments produced by Bowtie2 in SAM format were converted to sorted BAM format by SAMtools v. 0.1.19 (Li et al. 2009) and statistics for nucleotide coverage were generated with Qualimap v. 2.1 (Garcia-Alcalde et al. 2012). To evaluate the completeness of our genome assembly, CEGMA v. 2.5 (Parra et al. 2007) was run on the scaffolds to detect the percentage of conserved eukaryotic genes (CEG's) and BUSCO v. 1.1b1 (http://busco.ezlab.org/) was run on the scaffolds using the fungal profile (Dec. 19, 2014 release) to detect Universal Single-Copy Orthologs.

Genome annotation was carried out using webAugustus (Hoff \& Stanke 2013) running Augustus v. 3.0.3 (Stanke et al. 2006). Predicted proteins were compared against UniProt/Swiss-Prot manually curated fungal protein data set by BLASTp v. 2.2.28+. The BLAST hits with e-values less than $1.0 \mathrm{E}-100$ and similarity hits $\geq 90 \%$ were assumed to be orthologs and were given protein names in the annotation set. Genome Annotation Generator (http://genomeannotation. github.io/GAG/) and tbl2asn (http://www.ncbi.nlm.nih.gov/ genbank/tbl2asn2/) were used to validate annotations.

\section{RESULTS AND DISCUSSION}

Approximately 22 million reads, comprising $2.2 \mathrm{Gbp}$ of data, were assembled into 996 scaffolds resulting in an assembly of $30.8 \mathrm{Mb}$ with a GC content of $47.8 \%$. The N50 value was $92.3 \mathrm{~Kb}$ and the longest scaffold was $391 \mathrm{~Kb}$. The median nucleotide coverage across the whole assembly was $57 \mathrm{x}$. The assembled genome had a CEGMA score of $96.8 \%$ when calculated from the complete gene set and $98.4 \%$ when calculated from both partial and complete gene sets. Assessment of the completeness of the genome using BUSCO groups for fungi resulted in values of C: $99 \%$, [D: $6.8 \%$ ], F: $0.7 \%$, M: $0.1 \%, n: 1438$ (C: complete, [D: duplicated], F: fragmented, M: missed, n: genes). Therefore, the assembled genome covered most of the organism's gene content. After annotation and validation, the genome contained 12959 protein-coding genes. Of all suggested gene models, 12448 were complete (96.0\%), but 511 gene models lacked a start codon, stop codon or both $(4.0 \%)$. Mean gene length was $1388 \mathrm{bp}$, mean exon length was 437 $\mathrm{bp}$ and mean intron length was $85 \mathrm{bp}$. One other $P$. nordicum genome is accessioned in NCBI (JNNR), sequenced from a strain isolated from crop fields in Karlsruhe, Germany (UASWS BFE487). A comparative analysis has not yet been published, but as with our strain, the genome size was 30.4 $\mathrm{Mb}$ contained in 915 scaffolds, but the genome has less than half the coverage (at 20x) and only 46 genes were annotated.

This draft genome of a North American strain of $P$. nordicum, the first record of this species from Canada, represents a useful resource for biogeographical and comparative genomic studies of OTA (ochratoxin A) producing species of Penicillium, Aspergillus, and other related fungi. It will facilitate future gene knockout studies aiming to uncover the full OTA biosynthetic pathway in $P$. nordicum.

Authors: H.D.T. Nguyen* and K.A. Seifert

*Contact: hai.nguyen.1984@gmail.com

IMA Genome-F 5G

\section{Draft genome sequence of the banana pathogen Thielaviopsis musarum}

Thielaviopsis musarum is a pathogen of banana (Mitchell 1937, Riedl 1962) that typically infects banana fruits during maturation. This is especially true under conditions of high 
humidity, darkness and moderately steady temperatures (Riedl 1962).

Thielaviopsis musarum was previously treated as Ceratocystis musarum, but was transferred to Thielaviopsis as part of a major revision of the family Ceratocystidaceae by de Beer et al. (2014). The fungus was first reported as a new variety of $C$. paradoxa causing stem-end rot of banana in Australia (Mitchell 1937). Riedl (1962) isolated a similar fungus from banana stems in Vienna although the plant material probably originated elsewhere, and described it as a new species distinct from $C$. paradoxa. Although some authors regarded the species from banana as distinct from $C$. paradoxa (de Hoog 1974, Nag Raj \& Kendrick 1975), others viewed C. musarum as a synonym of $C$. paradoxa (Upadhyay 1981). These disputes have, however, been settled with DNA-based studies (Harrington 2009, de Beer et al. 2013) and T. musarum is now recognised as a distinct species in Thielaviopsis. The aim of this study was to sequence and assemble the whole genome of an isolate of $T$. musarum. This was undertaken to provide information allowing for the recognition of fungal genes that are associated with pathogenicity and other important biological properties in members of Ceratocystidaceae.

\section{SEQUENCED STRAIN}

New Zealand: on Musa sp., T.W. Canter Vischer (PREM 60962 - epitype, dried culture; CMW 1546 - ex-epitype culture).

\section{NUCLEOTIDE SEQUENCE ACCESSION NUMBERS}

This Whole Genome Shotgun project has been deposited at DDBJ/EMBL/GenBank under the accession LKBB00000000. The version described in this paper is version LKBB00000000.

\section{METHODS}

Isolate CMW1546 (CBS 139399) of Thielaviopsis musarum was grown in malt extract agar (MA). High quality DNA was isolated from harvested mycelium (Raeder \& Broda 1985) and sequencing was performed using the Genomics Analyzer IIx platform (Illumina) using paired-end libraries with insert sizes of approximately 350 and 600 bases. Reads with an average length of 97 bases were quality-trimmed using the software package CLC Genomics Workbench v. 6.0.1 (CLCBio, Aarhus, Denmark). The quality-filtered reads were assembled using the Velvet de novo assembler (Zerbino \& Birney 2008), with an optimized k-mer size of 77. We used SSPACE v.2.0 (Boetzer et al. 2011) to assemble contigs into scaffolds and gaps were filled using GapFiller v. 2.2.1 (Boetzer \& Pirovano 2012). The completeness of the assembled genome was assessed using the Benchmarking Universal Single-Copy Orthologs (BUSCO) tool, (Software v. 1.1b1 of May 2015; Simão et al. 2015). The BUSCO analysis was performed on all contigs $>1 \mathrm{~kb}$, making use of the fungal lineage dataset.
AUGUSTUS (Hoff \& Stanke 2013) and the gene models for Fusarium graminearum were used to identify putative open reading frames (ORFs).

\section{RESULTS AND DISCUSSION}

The Thielaviopsis musarum draft genome had an estimated size of 28493324 bases, a 95x coverage, N50 contig size of 103017 bases and a mean GC content of 49.17 $\%$. The assembly was composed of 672 contigs, of which 541 were larger than $1 \mathrm{~kb}$. Based on the BUSCO analysis, this assembly is $96 \%$ complete. A total of 1392 single-copy BUSCO orthologs were present, of which 78 were duplicated. Out of a possible 1438 BUSCO groups searched, 11 BUSCO groups were missing or fragmented. The final assembly was predicted to encode 6963 putative ORFs at a density of 244 ORFs/Mb.

The T. musarum genome appears to be relatively small and harbours fewer genes than other Sordariomycetes (e.g., Fusarium fujikuroi, 43.8 Mb with 14813 ORFs; Cryphonectria parasitica, 43.9Mb with 11184 ORFs) (Wiemann et al. 2013; http://genome.jgi.doe.gov/Crypa2/Crypa2.home.html). The genome size of $T$. musarum was, however, in the same range of some species of Ceratocystidaceae such as Ceratocystis manginecans (of $31.7 \mathrm{Mb}$ with $7494 \mathrm{ORFs}$ ), C. albifundus albifundus (27.1 Mb with 6967 ORFs), C. fimbriata (29.4 $\mathrm{Mb}$ with 7266 ORFs), Huntiella omanensis (31.5 Mb with 8395 ORFs) and $H$. moniliformis (25.5 Mb with 6832 ORFs) (Wilken et al. 2013, van der Nest et al. 2014a, b).

The Thielaviopsis musarum genome was only marginally larger than that of $T$. puntulata (accession number: LAEV00000000) with its $28.1 \mathrm{Mb}$ genome. However, $T$. puntulata was reported to encode 5480 ORFs (Wingfield et al. 2015) as opposed to the 6963 of T. musarum, suggesting a higher ORF density for the latter (i.e., $244 \mathrm{ORFs} / \mathrm{Mb}$ for $T$. musarum vs. 195 ORFs/Mb for T. puntulata). Future research should, therefore, consider whether these differences in genome size and ORF density could be ascribed to differences in the methodologies used to sequence and annotate the respective genomes. Overall, these genomes will provide interesting perspectives regarding the development and evolution of important biological traits in these fungi.

Authors: M.A Sayari* , C. Trollip, K. Naidoo, B.D. Wingfield, and M.J. Wingfield *Contact: Mohammad.Sayari@fabi.up.ac.za

\section{ACKNOWLEDGEMENTS}

Genome sequencing of Penicillium nordicum DAOMC 185683 was funded by Growing Forward 2 funding from Agriculture \& AgriFood Canada, with additional support from Canadian Safety and Security Programme grant CRTI 09-462RD/CSSP 30vv01. We thank Ekaterina Ponomareva for technical assistance.

For the Ceratocystis eucalypticola, Chrysoporthe cubensis, C. deuterocubensis, Fusarium temperatum, and Graphilbum fragrans genomes we recognise the co-funding by the Genomics Research Institute (University of Pretoria), the University of Pretoria Research 
Development Programme, the DST/NRF Centre of Excellence in Tree Health Biotechnology (FABI, University of Pretoria), and the National Research Foundation (NRF) (Grant number 87332).

Studies on Davidsoniella virescens and Thielaviopsis musarum were funded by the University of Pretoria, members of the Tree Protection Cooperative Program (TPCP), the National Research Foundation (NRF)/Department of Science and Technology (DST), Centre of Excellence in Tree Health Biotechnology (CTHB), and the THRIP initiative of the Department of Trade and Industry (DTI) in South Africa for financial assistance. This work was based on the research supported in part by a number of grants from the National Research Foundation of South Africa (includes Grant specific unique reference numbers (UID) 83924 and 87332). The Grant holders acknowledge that opinions, findings and conclusions or recommendations expressed in any publication generated by the NRF supported research are that of the author(s), and that the NRF accepts no liability whatsoever in this regard.

\section{REFERENCES}

Alfenas A, Hubbes M, Couto L (1982) Effect of phenolic compounds from Eucalyptus on the mycelial growth and conidial germination of Cryphonectria cubensis. Canadian Journal of Botany 60: 2535-2541.

Bal TL, Richter DL, Storer AJ, Jurgensen MF (2013) The relationship of the sapstreak fungus, Ceratocystis virescens, to sugar maple dieback and decay in Northern Michigan. American Journal of Plant Sciences 4: 436-43.

Bankevich A, Nurk S, Antipov D, Gurevich AA, Dvorkin M, et al. (2012) SPAdes: a new genome assembly algorithm and its applications to single-cell sequencing. Journal of Computational Biology 19: 455-477.

Barnes I, Roux J, Wingfield BD, O'Neill M, Wingfield MJ (2003) Ceratocystis fimbriata infecting Eucalyptus grandis in Uruguay. Australasian Plant Pathology 32: 361-366.

Belbahri L (2015) Genome sequence of Ceratocystis platani, a major pathogen of plane trees. URL http://www.ncbi.nlm.nih.gov/ nuccore/814603118.

Boetzer M, Henkel CV, Jansen HJ, Butler D, Pirovano W (2011) Scaffolding pre-assembled contigs using SSPACE. Bioinformatics 27: 578-579.

Boetzer M, Pirovano W (2012) Toward almost closed genomes with GapFiller. Genome Biology 13: R56.

Bolger AM, Lohse M, Usadel B (2014) Trimmomatic: a flexible trimmer for Illumina sequence data. Bioinformatics 30: 2114-2120.

Campbell MS, Holt C, Moore B, Yandell M (2014) Genome annotation and curation using MAKER and MAKER-P. Current Protocols in Bioinformatics: 4.11. 1-4.11. 39.

Cantarel BL, Korf I, Robb SM, Parra G, Ross E, et al. (2008) MAKER: an easy-to-use annotation pipeline designed for emerging model organism genomes. Genome Research 18: 188-196.

Chikhi R, Medvedev P (2014) Informed and automated k-mer size selection for genome assembly. Bioinformatics 30: 31-37.

Chungu D, Gryzenhout M, Muimba-Kankolongo A, Wingfield MJ, Roux J (2010) Taxonomy and pathogenicity of two novel Chrysoporthe species from Eucalyptus grandis and Syzygium guineense in Zambia. Mycological Progress 9: 379-393.

Davidson RW (1944) Two American hardwood species of Endoconidiophora described as new. Mycologia 45: 579-86. de Beer ZW, Duong TA, Barnes I, Wingfield BD, Wingfield MJ (2014) Redefining Ceratocystis and allied genera. Studies in Mycology 79: 187-219.

de Beer ZW, Seifert KA, Wingfield MJ (2013) A nomenclator for ophiostomatoid genera and species in the Ophiostomatales and Microascales. In: The Ophiostomatoid Fungi: expanding frontiers (Seifert KA, de Beer ZW, Wingfield MJ, eds): 245-322. [CBS Biodiversity Series vol. 12.] Utrecht: CBS-KNAW Fungal Biodiversity Centre.

de Beer ZW, Wingfield MJ (2013) Emerging lineages in the Ophiostomatales. In: The Ophiostomatoid Fungi: expanding frontiers (Seifert KA, de Beer ZW, Wingfield MJ, eds): 21-46. [CBS Biodiversity Series vol. 12.] Utrecht: CBS-KNAW Fungal Biodiversity Centre.

de Hoog GS (1974) The genera Blastobotrys, Sporothrix, Calcarisporium and Calcarisporiella gen. nov. Studies in Mycology 7: 1-84.

de Vos L, Myburg AA, Wingfield MJ, Desjardins AE, Gordon TR, et al. (2007) Complete genetic linkage maps from an interspecific cross between Fusarium circinatum and Fusarium subglutinans. Fungal Genetics and Biology 44: 701-714.

de Vos L, Steenkamp ET, Martin SH, Santana QC, Fourie G, et al. (2014) Genome-wide macrosynteny among Fusarium species in the Gibberella fujikuroi complex revealed by amplified fragment length polymorphisms. PLoS One 9: e114682.

de Vos L, van der Merwe NA, Wingfield MJ, Myburg AA, Wingfield BD (2013) Transmission ratio distortion in an interspecific cross between Fusarium circinatum and Fusarium subglutinans. Genes and Genomics 35: 177-183.

de Vos L, van der Nest MA, van der Merwe NA, Myburg AA, Wingfield MJ, et al. (2011) Genetic analysis of growth, morphology and pathogenicity in the $F_{1}$ progeny of an interspecific cross between Fusarium circinatum and Fusarium subglutinans. Fungal Biology 115: 902-908.

Dean RA, Talbot NJ, Ebbole DJ, Farman ML, Mitchell TK, et al. (2005) The genome sequence of the rice blast fungus Magnaporthe grisea. Nature 434: 980-986.

DiGuistini S, Wang Y, Liao NY, Taylor G, Tanguay P, et al. (2011) Genome and transcriptome analyses of the mountain pine beetle-fungal symbiont Grosmannia clavigera, a lodgepole pine pathogen. Proceedings of the National Academy of Sciences, USA 108: 2504-2509.

Duong TA, de Beer ZW, Wingfield BD, Wingfield MJ (2013) Characterization of the mating-type genes in Leptographium procerum and Leptographium profanum. Fungal Biology 117: $411-421$.

Fourie A, Wingfield MJ, Wingfield BD, Barnes I (2015) Molecular markers delimit cryptic species in Ceratocystis sensu stricto. Mycological Progress 14: 1-18.

Frisvad JC, Samson RA (2004) Polyphasic taxonomy of Penicillium subgenus Penicillium: a guide to identification of food and airborne terverticillate Penicillia and their mycotoxins. Studies in Mycology 49: 1-174.

Galagan JE, Calvo SE, Borkovich KA, Selker EU, Read ND, et al. (2003) The genome sequence of the filamentous fungus Neurospora crassa. Nature 422: 859-868.

Garcia-Alcalde F, Okonechnikov K, Carbonell J, Cruz LM, Gotz S, et al. (2012) Qualimap: evaluating next-generation sequencing alignment data. Bioinformatics 28: 2678-2679.

Geisen R, Schmidt-Heydt M, Karolewiez A (2006) A gene cluster of 
the ochratoxin A biosynthetic genes in Penicillium. Mycotoxin Research 22: 134-141.

Gryzenhout M, Myburg H, van der Merwe NA, Wingfield BD, Wingfield MJ (2004) Chrysoporthe, a new genus to accommodate Cryphonectria cubensis. Studies in Mycology 50: 119-142.

Gryzenhout M, Myburg H, Wingfield BD, Montenegro F, Wingfield MJ (2005) Chrysoporthe doradensis sp. nov. pathogenic to Eucalyptus in Ecuador. Fungal Diversity 20: 39-57.

Gryzenhout M, Rodas CA, Portales MJ, Clegg P, Wingfield BD, et al. (2006) Novel hosts of the Eucalyptus canker pathogen Chrysoporthe cubensis and a new Chrysoporthe species from Colombia. Mycological Research 110: 833-845.

Gurevich A, Saveliev V, Vyahhi N, Tesler G (2013) QUAST: quality assessment tool for genome assemblies. Bioinformatics 29: 1072-1075.

Hadjeba-Medjdoub K, Tozlovanu M, Pfohl-Leszkowicz A, Frenette C, Paugh RJ, et al. (2012) Structure-activity relationships imply different mechanisms of action for ochratoxin A-mediated cytotoxicity and genotoxicity. Chemical Research in Toxicology 25: 181-190.

Haridas S, Wang Y, Lim L, Alamouti SM, Jackman S, et al. (2013) The genome and transcriptome of the pine saprophyte Ophiostoma piceae, and a comparison with the bark beetle-associated pine pathogen Grosmannia clavigera. BMC Genomics 14: 373.

Harrington TC (2009) The genus Ceratocystis. Where does the oak wilt fungus fit? In: Proceedings of the 2nd National Oak Wilt Sym (Appel DN, Billings RF, eds). Austin, TX: USDA Forest Service.

Harrington TC, McNew D, Steimel J, Hofstra D, Farrell R (2001) Phylogeny and taxonomy of the Ophiostoma piceae complex and the Dutch Elm disease fungi. Mycologia 93: 111-136.

Heath RN, Gryzenhout M, Roux J, Wingfield MJ (2006) Discovery of the canker pathogen Chrysoporthe austroafricana on native Syzygium spp. in South Africa. Plant Disease 90: 433-438.

Hodges C, Reis M, Ferreira F, Henfling J (1976) O cancro do eucalipto causado por Diaporthe cubensis [Eucalyptus spp.; Fungo; Brasil]. Fitopatologia Brasileira 1: 129-170.

Hodges CS, Geary TF, Cordell CE (1979) The occurrence of Diaporthe cubensis on Eucalyptus in Florida, Hawaii, and Puerto Rico. Plant Disease Reporter 63: 216-220.

Hoff KJ, Stanke M (2013) WebAUGUSTUS - a web service for training AUGUSTUS and predicting genes in eukaryotes. Nucleic Acid Research 41: W123-W128.

Houbraken J, Samson RA (2011) Phylogeny of Penicillium and the segregation of Trichocomaceae into three families. Studies In Mycology 70: 1-51.

Iturritxa E, Ganley RJ, Wright J, Heppe E, Steenkamp ET, et al. (2011) A genetically homogenous population of Fusarium circinatum causes pitch canker of Pinus radiate in the Basque Country, Spain. Fungal Biology 115: 288-295.

Jacobs K, Seifert KA, Harrison KJ, Kirisits T (2003) Identity and phylogenetic relationships of ophiostomatoid fungi associated with invasive and native Tetropium species (Coleoptera: Cerambycidae) in Atlantic Canada. Canadian Journal of Botany. 81: 316-329.

Jankowiak R, Bilański P (2013) Diversity of ophiostomatoid fungi associated with the large pine weevil, Hylobius abietis, and infested Scots pine seedlings in Poland. Annals of Forest Science 70: 391-402.
Jurgenson JE, Zeller KA, Leslie JF (2002) Expanded genetic map of Gibberella moniliformis (Fusarium verticillioides). Applied and Environmental Microbiology 68: 1972-1979.

Karolewiez A, Geisen R (2005) Cloning a part of the ochratoxin A biosynthetic gene cluster of Penicillium nordicum and characterization of the ochratoxin polyketide synthase gene. Systematic and Applied Microbiology 28: 588-595.

Khoshraftar S, Hung S, Khan S, Gong Y, Tyagi V, et al. (2013) Sequencing and annotation of the Ophiostoma ulmi genome. BMC Genomics 14: 162.

Kim G-H, Kim J-J, Breuil C (2007) Sap-staining fungi from logs and boards of two commercially important pines in Korea. Holzforschung. 61: 333-336.

Kurtz S, Phillippy A, Delcher AL, Smoot M, Sumway M, et al. (2004) Versatile and open software for comparing large genomes. Genome Biology 5: R12.

Kvas M, Marasas WFO, Wingfield BD, Wingfield MJ, Steenkamp ET (2009) Diversity and evolution of Fusarium species in the Gibberella fujikuroi complex. Fungal Diversity 34: 1-21.

Laia M, Alfenas A, Harrington T (1999) Isolation, detection in soil, and inoculation of Ceratocystis fimbriata, causal agent of wilting, dieback and canker in Eucalyptus. In: Proceedings of the 12th biennial conference of the Australasian Plant Pathology Society. eds): 77.

Langmead B, Salzberg SL (2012) Fast gapped-read alignment with Bowtie 2. Nature Methods 9: 357-359.

Lee DH, Roux J, Wingfield BD, Wingfield MJ (2015) Variation in growth rates and aggressiveness of naturally occurring selffertile and self-sterile isolates of the wilt pathogen Ceratocystis albifundus. Plant Pathology 64: 1103-1109.

Li H, Handsaker B, Wysoker A, Fennell T, Ruan J, et al. (2009) The Sequence Alignment/Map format and SAMtools. Bioinformatics 25: 2078-2079.

Ma L-J, van der Does HC, Borkovich KA, Coleman JJ, Daboussi M-J., et al. (2010) Comparative genomics reveals mobile pathogenicity chromosomes in Fusarium. Nature 464: 367-373.

Mathiesen-Käärik A (1953) Eine Übersicht über die gewöhnlichsten mit Borkenkäfer assoziierten Bläuepilze in Schweden und einige für Schweden neue Bläuepilze. Meddelanden från Statens Skogsforskiningsinstitut. 43: 1-74.

Mayers CG, McNew DL, Harrington TC, Roeper RA, Fraedrich SW, et al. (2015) Three genera in the Ceratocystidaceae are the respective symbionts of three independent lineages of ambrosia beetles with large, complex mycangia. Fungal Biology doi:10.1016/junbio.2015.1008.1002.

Mitchell RS (1937) Stem end rot of bananas with special reference to the physiological relationships of Thielaviopsis paradoxa (de Seynes) von Hohn. Journal of the Council for Scientific and Industrial Research 10: 123-130.

Myburg H, Gryzenhout M, Wingfield BD, Wingfield MJ (2002) $\beta$-Tubulin and histone $\mathrm{H} 3$ gene sequences distinguish Cryphonectria cubensis from South Africa, Asia, and South America. Canadian Journal of Botany 80: 590-596.

Myburg H, Gryzenhout M, Wingfield BD, Wingfield MJ (2003) Conspecificity of Endothia eugeniae and Cryphonectria cubensis: a re-evaluation based on morphology and DNA sequence data. Mycoscience 44: 187-196.

Nag Raj TR, Kendrick WB (1975) A Monograph of Chalara and allied Genera. Laurier W, Waterloo, ON: Waterloo University Press.

Nakabonge G, Roux J, Gryzenhout M, Wingfield MJ (2006). Distribution of Chrysoporthe canker pathogens on Eucalyptus 
and Syzygium spp. in Eastern and Southern Africa. Plant Disease Reporter 90: 734-740.

Nikolenko SI, Korobeynikov Al, Alekseyev MA (2013) BayesHammer: Bayesian clustering for error correction in single-cell sequencing. BMC Genomics 14 (Suppl. 1): S7.

Oliveira L, Harrington TC, Ferreira MA, Damacena M, Al-Sadi AM, et al. (2015) Species or genotypes? Reassessment of four recently described species of the Ceratocystis wilt pathogen, Ceratocystis fimbriata, on Mangifera indica. Phytopathology 105: 1229-1244.

Paciura D, Zhou X, de Beer ZW, Jacobs K, Ye H, et al. (2010) Characterisation of synnematous bark beetle-associated fungi from China, including Graphium carbonarium sp. nov. Fungal Diversity 40: 75-88.

Parra G, Bradnam K, Korf I (2007) CEGMA: a pipeline to accurately annotate core genes in eukaryotic genomes. Bioinformatics 23: 1061-1067.

Pitt JI, Wild CP, Baan RA, Gelderblom WCA, Miller JD, et al. (2012) Improving Public Health through Mycotoxin Control. [Scientific Publications Series no. 158.] Lyon:. International Agency for Research on Cancer.

Raeder U, Broda P (1985) Rapid preparation of DNA from filamentous fungi. Letters in Applied Microbiology 1: 17-20.

Riedl H (1962) Ceratocystis musarum sp. n., die heuptfruchtform der Thielaviopsis-Art von bananenstielen. Sydowia 15: 247-251.

Rodas CA, Gryzenhout M, Myburg H, Wingfield BD, Wingfield MJ (2005) Discovery of the Eucalyptus canker pathogen Chrysoporthe cubensis on native Miconia (Melastomataceae) in Colombia. Plant Pathology 54: 460-470.

Romon P, Zhou X, Iturrondobeitia J, Wingfield M, Goldarazena A (2007) Ophiostoma species (Ascomycetes: Ophiostomatales) associated with bark beetles (Coleoptera: Scolytinae) colonizing Pinus radiata in northern Spain. Canadian Journal of Microbiology 53: 756-767.

Roux J, Coutinho T, Mujuni Byabashaija D, Wingfield MJ (2001) Diseases of plantation Eucalyptus in Uganda: research in action. South African Journal of Science 97: 16-18.

Roux J, Heath RN, Labuschagne L, Nkuekam GK, Wingfield MJ (2007) Occurrence of the wattle wilt pathogen, Ceratocystis albifundus on native South African trees. Forest Pathology 37: 292-302.

Roux J, van Wyk M, Hatting H, Wingfield MJ (2004) Ceratocystis species infecting stem wounds on Eucalyptus grandis in South Africa. Plant Pathology 53: 414-421.

Roux J, Wingfield M (2013) Ceratocystis species on the African continent, with particular reference to $C$. albifundus, an African species in the C. fimbriata sensu lato species complex. In: The Ophiostomatoid Fungi: expanding frontiers (Seifert KA, de Beer ZW, Wingfield MJ, eds): 131-138. [CBS Biodiversity Series vol. 12.] Utrecht: CBS-KNAW Fungal Biodiversity Centre.

Roux J, Wingfield MJ (2009) Ceratocystis species: emerging pathogens of non-native plantation Eucalyptus and Acacia species. Southern Forests 71: 115-120.

Roux J, Wingfield MJ, Bouillet JP, Wingfield BD, Alfenas AC (2000) A serious new wilt disease of Eucalyptus caused by Ceratocystis fimbriata in Central Africa. Forest Pathology 30: 175-184.

Samson RA, Seifert KA, Kuijpers AFA, Houbraken J, Frisvad JC (2004) Phylogenetic analysis of Penicillium subgenus Penicillium using partial $\beta$-tubulin sequences. Studies in Mycology 49: 175-200.

Scauflaire J, Gourgue M, Munaut F (2011) Fusarium temperatum sp. nov. from maize, an emergent species closely related to Fusarium subglutinans. Mycologia 103: 586-597.
Simão FA, Waterhouse RM, loannidis P, Kriventseva EV, Zdobnov EM (2015) BUSCO: assessing genome assembly and annotation completeness with single-copy orthologs. Bioinformatics 31: 3210-3212.

Simpson JT, Wong K, Jackman SD, Schein JE, Jones SJM, et al. (2009) ABySS: a parallel assembler for short read sequence data. Genome Research 19: 1117-1123.

Stanke M, Keller O, Gunduz I, Hayes A, Waack S, et al. (2006) AUGUSTUS: $a b$ initio prediction of alternative transcripts. Nucleic Acids Research 34 (Web Server issue): W435-439.

Stanke M, Morgenstern B (2005) AUGUSTUS: a web server for gene prediction in eukaryotes that allows user-defined constraints. Nucleic Acids Research 33 (Suppl 2): W465-W467.

Stanke M, Steinkamp R, Waack S, Morgenstern B (2004) AUGUSTUS: a web server for gene finding in eukaryotes. Nucleic Acids Research 32: 309-312.

Stanke M, Tzvetkova A, Morgenstem B (2006) AUGUSTUS at EGASP: using EST, protein and genomic alignments for improved gene prediction in the human genome. Genome Biology 7: S11.1-S.8.

Steenkamp ET, Wingfield BD, Coutinho TA, Wingfield MJ, Marasas WFO (1999). Differentiation of Fusarium subglutinans f. sp. pini by Histone Gene Sequence Data. Applied and Environmental Microbiology 65: 3401-3406.

Teixeira MM, de Almeida LG, Kubitschek-Barreira P, Alves FL, Kioshima ÉS, et al. (2014) Comparative genomics of the major fungal agents of human and animal Sporotrichosis: Sporothrix schenckii and Sporothrix brasiliensis. BMC Genomics 15: 943.

Upadhyay HP (1981) A Monograph of Ceratocystis and Ceratocystiopsis. Athens, GA: University of Georgia Press.

van der Merwe NA, Gryzenhout M, Steenkamp ET, Wingfield BD, Wingfield MJ (2010) Multigene phylogenetic and population differentiation data confirm the existence of a cryptic species within Chrysoporthe cubensis. Fungal Biology 114: 966-979.

van der Nest MA, Beirn LA, Crouch JA, Demers JE, de Beer ZW, et al. (2014a) IMA Genome-F 3: Draft genomes of Amanita jacksonii, Ceratocystis albifundus, Fusarium circinatum, Huntiella omanensis, Leptographium procerum, Rutstroemia sydowiana, and Sclerotinia echinophila. IMA Fungus 5: 473-486.

van der Nest MA, Bihon W, De Vos L, Naidoo K, Roodt D, et al. (2014b) IMA Genome-F 2: Ceratocystis manginecans, Ceratocystis moniliformis, Diplodia sapinea: Draft genome sequences of Diplodia sapinea, Ceratocystis manginecans, and Ceratocystis moniliformis. IMA Fungus 5: 135-140.

van Wyk M, Roux J, Nkuekam GK, Wingfield BD, Wingfield MJ (2012) Ceratocystis eucalypticola sp. nov. from Eucalyptus in South Africa and comparison to global isolates from this tree. IMA Fungus 3: 45-58.

van Wyk M, Wingfield BD, Wingfield MJ (2013) Ceratocystis species in the Ceratocystis fimbriata complex. In: The Ophiostomatoid Fungi: expanding frontiers (Seifert KA, de Beer ZW, Wingfield MJ, eds): 65-73. [CBS Biodiversity Series vol. 12.] Utrecht: CBSKNAW Fungal Biodiversity Centre.

Visagie CM, Houbraken J, Frisvad JC, Hong SB, Klaassen CHW, et al. (2014b) Identification and nomenclature of the genus Penicillium. Studies in Mycology 78: 343-371.

Visagie CM, Varga J, Houbraken J, Meijer M, Kocsube S, et al. (2014a) Ochratoxin production and taxonomy of the yellow aspergilli (Aspergillus section Circumdati). Studies in Mycology 78: 1-61. 
Wargo PM, Harrington TC (1991) Host stress and susceptibility. In: Armillaria Root Disease (Shaw CG Kile GA, eds): 88-101. [Agriculture Handbook no. 691.] Washington, DC: USDA Forest Service.

Wiemann P, Sieber CM, von Bargen KW, Studt L, Niehaus EM, et al (2013) Deciphering the cryptic genome: genome-wide analyses of the rice pathogen Fusarium fujikuroi reveal complex regulation of secondary metabolism and novel metabolites. PLoS Pathogen 9: e1003475.

Wilken PM, Steenkamp ET, Wingfield MJ, de Beer ZW, Wingfield BD (2013) IMA Genome-F 1: Ceratocystis fimbriata: Draft nuclear genome sequence for the plant pathogen, Ceratocystis fimbriata. IMA Fungus 4: 357-358.

Wingfield BD, Ades PK, Al-Naemi FA, Beirn LA, Bihon W, et al. (2015) IMA Genome-F 4: Draft genome sequences of Chrysoporthe austroafricana, Diplodia scrobiculata, Fusarium nygamai, Leptographium lundbergii, Limonomyces culmigenus, Stagonosporopsis tanaceti, and Thielaviopsis punctulata. IMA Fungus 6: 233-248.

Wingfield BD, Steenkamp ET, Santana QC, Coetzee MPA, Bam $S$, et al. (2012) First fungal genome sequence from Africa: a preliminary analysis. South African Journal of Science 108: 1-2.
Wingfield BD, van Wyk M, Roos H, Wingfield MJ (2013) Ceratocystis: emerging evidence for discrete generic boundaries. In: The Ophiostomatoid Fungi: expanding frontiers (Seifert KA, de Beer ZW, Wingfield MJ, eds): 57-64. [CBS Biodiversity Series vol. 12.] Utrecht: CBS-KNAW Fungal Biodiversity Centre.

Wingfield MJ (2003) Increasing threat of diseases to exotic plantation forests in the Southern Hemisphere: lessons from Cryphonectria canker. Australasian Plant Pathology 32: 133-139.

Wingfield MJ, Swart WJ, Abear BJ (1989) First Record of Cryphonectria canker of Eucalyptus in South Africa. Phytophylactica 20: 311-313.

Xu J-R, Yan K, Dickman MB, Leslie JF (1995) Electrophoretic karyotypes distinguish the biological species of Gibberella fujikuroi (Fusarium section Liseola). Molecular Plant-Microbe Interactions 8: 74-84.

Zerbino DR, Birney E (2008) Velvet: Algorithms for de novo short read assembly using de Bruijn graphs. Genome Research 18: 821-829.

Zhou X, de Beer ZW, Wingfield MJ (2006) DNA sequence comparisons of Ophiostoma spp., including Ophiostoma aurorae sp. nov., associated with pine bark beetles in South Africa. Studies in Mycology 55: 269-277. 